\title{
CHANGES IN THE PRESCHOOL EDUCATION SYSTEM OF REPUBLIC OF KARAKALPAKSTAN
}

\author{
Ikmet Elmuratov ${ }^{1}$, Gulsara Tureeva ${ }^{2}$, Erjanova Gulchehra ${ }^{3}$ \\ ${ }^{1}$ Researcher, Department of Archeology Karakalpak State University \\ ${ }^{2}$ Associate professor, Department of Archeology Karakalpak State Universityt_gulsara@karsu.uz \\ ${ }^{3}$ Teacher, Academic Lyceum in Karakalpak State University, o.hakimbay@karsu.uz
}

\begin{abstract}
In the modern world, due to the wide spread of integration processes in education, great changes are taking place. Indeed, at the beginning of the new century, it became clear that education is incompatible with socio-economic conditions. As a result, the search for new ways of developing education has led to the renewal of the content and methods of teaching, the introduction of new organizational forms and changes in the relationships between subjects. These modernization processes have a significant impact on the development of the education system in many countries. Analysis of the formation of education in the country and its regions allows us to fully demonstrate the leading trends in the development of the educational system.
\end{abstract}

Keywords:education system, preschool education,

Article Received: 10 August 2020, Revised: 25 October 2020, Accepted: 18 November 2020

Introduction

The first link plays an important role in the system of continuing education. The main activity of a non-governmental preschool education institution is to provide educational services to the population in accordance with the state requirements for preschool education.

The non-governmental preschool educational institution in accordance with the Constitution and laws of the Republic of Uzbekistan, resolutions and other documents of the OliyMajlis of the Republic of Uzbekistan, decrees, resolutions and orders of the President of the Republic of Uzbekistan, other normative legal acts, as well as The statute applies[1].

\section{Main part}

The charter of a non-governmental preschool educational institution shall be developed in accordance with the procedure for developing the charter of the educational institution approved by the Cabinet of Ministers №5 of January 5, 1998, approved by its founder and registered with the relevant state bodies.Kindergartens, which were part of farms and institutions from the years of independence to 1998, were transferred to the balance of local governments. However, 269 kindergartens were not repaired and 139 were unable to operate due to lack of funds. Most of them were in Amudarya, Turtkul, Kegeyli, Beruni and Chimbay districts.

In the Republic of Karakalpakstan[8], [9], [10] developed the Law "On Education", the National Program of Personnel Training, the Presidential Decree "On reforming the system of education and training, the formation of a fully developed generation" and future projects for 19982005 was reviewed[2].

There are 303 (21,004 children) preschools in the public education departments and 72 (5,048 children) affiliated with other organizations, which involve $12.3 \%$ of preschool children. There are innovations in the renewal of service in preschool education, the preparation of children for school and the intithincrease in the number of "kindergarten-school" institutions.

In order to further carry out reforms in the field, on October 25, 2007 the Cabinet of Ministers adopted a resolution "On approval of normative legal acts in the field of preschool education." This document approves regulations on public preschools, nonstate preschools and short-term groups. This allowed for further improvement of preschool education institutions. Resolution of the Board of the Ministry of Public Education of the Republic of Karakalpakstan $\mathrm{N}^{\circ} 5 / 2$ of June 5, 2009 on the implementation of the program "State requirements for the education of preschool children" and "Child of the third millennium" in preschool institutions of the Kungrad district department of public education It was noted that a number of measures have been taken to improve the quality and efficiency of rehabilitation work. According to that, 3210 children are educated in 31 pre-school educational institutions for 4,137 places ( 5 of them belong to organizations) in Kungrad district. Involvement of preschool children in preschool education in the district is $23.4 \%$ ( $17 \%$ in the country at that time), 47 out of 354 teachers working in this field are higher (13.2\%), 262 are secondary special (74.0\%), 1 is an incomplete higher $(0.2 \%)$ and $27(7.4)$ are graduates of one-year courses.

A number of positive measures have been taken to strengthen the material and technical base of preschool education institutions No. 7, 9, 16, 17, $20,22,25$ in the district, as well as landscaping and beautification. For example, UURB (headed by SaidvaqqosIsakov), which sponsors Preschool No. 25 , renovated and put into operation a children's swimming pool for 3 million soums. In the preschool $N^{\circ} 20$ the roof of the building was slated 
for 22 million 935 thousand soums, the "Xalq Bank" of the district provided a refrigerator for 200.0 thousand soums. The Kungrad Soda Plant, which sponsors Preschool $\mathrm{N}^{\circ} 16$, donated toys worth 3 million soums and repaired them for 4 million soums. With the help of the local authorities, 26 million soums were spent on the repair of preschool $\mathrm{N}^{\circ} 14,27$ million soums at the expense of sponsors, and 15 million soums on the repair of preschool $\mathrm{N}^{\mathrm{o}} 11$.

In the 2008-2009 academic year, repairs were carried out at a cost of 104.4 million soums, 17.3 million soums were allocated for hard equipment, 12,137.0 thousand soums for soft equipment, and 800.0 thousand soums for medicines.However, in addition to the positive work being done in preschools of Kungrad district, it was found that there are shortcomings. It is clear that the effectiveness of the educational work of each educational institution depends on the provision of personnel working in it. In this regard, not all organizations have enough staff. In particular, agronomists, accountants and nurses have been criticized for working as educators in preschools 10 and 26 .

The state pays special attention to strengthening their material and technical base, providing them with technical and educational manuals. For example, every year an average of ten percent of the funds allocated for education in the country is directed to the provision of preschool education. In the first half of 2012, this figure exceeded 343.9 billion soums. Of course, in this process, a number of events were held, which analyzed the work aimed at improving the educational work in preschool education, improving the skills of teachers, the introduction of new modern pedagogical technologies in the educational process[3].

The Presidential Decree of February 7, 2017 "On the Strategy of Actions for the Further Development of the Republic of Uzbekistan" set a number of tasks for the development of the social sphere, including education. The document envisages work on strengthening and improving the material and technical base of institutions, construction of new ones, as well as reconstruction and overhaul of existing ones, equipping them with modern teaching and laboratory equipment, computers and textbooks.[11, 12, 13, 14, 15, 16, 17]

Improving the activities of preschool education institutions has been identified by the President as one of the priorities of state policy. Extensive changes in this area began in September 2017 with the emergence of the line ministry. With the establishment of the Ministry of Preschool Education, a number of major changes have taken place, one of the main achievements of which is the expansion of the network of public and private preschool institutions. Currently, more than 7,100 kindergartens are successfully operating in the country. The proportion of children covered by the pre-school education system has increased significantly. By the end of 2018, more than 900,000 boys and girls between the ages of three and seven attended kindergarten, representing 37.7 percent of children of the appropriate age.[18, 19, $20,21]$

The Resolution of the Ministry of Public Education, the Ministry of Health, the Ministry of Employment and Labor Relations, and local authorities in the field of preschool education was dissatisfied by the Resolution "On measures to radically improve the system of pre-school education" adopted on September 9, 2017.

The resolution envisages the introduction of a modern mechanism for the management of preschool education, the implementation of comprehensive efforts to improve the process of education and training, improve the infrastructure and logistics of preschool education.

The implementation of this decision has allowed the system of preschool education in our country to reach a qualitatively new level, improve the infrastructure and logistics of educational institutions[4].

During the years of independence, the education system and upbringing of a harmoniously developed generation have been included in the list of priority areas of state policy. However, the analysis shows that the effectiveness of efforts in the field of preschool education is insufficient.In particular, over the past 20 years, the number of state-owned preschools has decreased by $45 \%$, and today the coverage of children with preschool education in the country is $30 \%$. Also, the material and technical base of preschool education institutions does not meet modern requirements. There are no variable programs in the pre-school education system, alternative, flexible models for preparing children for school are not sufficiently developed, and special state educational programs aimed at social, individual, affective, speech, mathematical, physical and creative development, environmental awareness are introduced in developed countries. not done.

The majority of teachers working in public preschools have secondary special education, which does not give them the confidence to prepare children for school education at the required level.Due to these problems, the Decree of the President of the Republic of Uzbekistan dated September 9, 2017 "On measures to radically improve the system of preschool education" was published.

In order to fulfill the tasks set by this resolution of the President and the special order of the Cabinet of Ministers of the Republic of Uzbekistan dated August 16, 2018, the order of the 
Mayor of Nukus dated September 11, 2018 was adopted and proposals of business entities were considered. The decree provides for the organization of "Outsourced" nutrition in 51 kindergartens of the Nukus city department of preschool education in 10 preschool institutions in the city.

In addition, 4 entrepreneurs were selected on the basis of a competition to organize a healthy diet in a new way in 10 preschool institutions of the department. Each entrepreneur was assigned 10 kindergartens in the city. For example, preschools $6,12,14,46$ to TabassumNukus LLC, preschools 26, 27, 48 to Nukus Aziz sauda LLC, and preschools 34 and 35 Nukusbarakasauda "LLC and preschool No. 20 were merged with" Ideal Nukus "LLC, and on October 2, 2018, entrepreneurs started their work on healthy and safe nutrition of children.

The Ministry of Preschool Education was established by the Decree of President ShavkatMirziyoyev dated September 30, 2017 "On measures to radically develop the management of the preschool education system." The main tasks of the new ministry are to gradually cover all children in the preschool education system, to create a network of competitive state and non-state MTCs, to introduce into practice alternative forms of preschool education and child rearing.

Extensive work has been carried out in the Republic of Karakalpakstan to implement the decree. The decision of the Presidium of the JokorkuKengesh of the Republic No229 of October 6, 2017 was adopted and on this basis the Ministry of Preschool Education was established in the Republic of Karakalpakstan. There are 318 preschool educational institutions in the region, three of which are private and 7 are run by various organizations. 48,106 people, $32 \%$ of the total number of children are educated in them[5].

The visit of President ShavkatMirziyoyev to the Republic of Karakalpakstan in December 2017 began at the preschool No. 8 in Chimbay district. The head of state got acquainted with the conditions created for children in the kindergarten, and it is not in vain that we pay special attention to the pre-school education system, the president said. If we do not pay attention to the upbringing of young people today, tomorrow may be too late. Preschools should be built based on the climatic conditions of Karakalpakstan. Each room should be provided with a heated floor. In addition, it is necessary to reconsider the system of training for this area, for which it is necessary to organize special courses at higher education institutions. The level of educators is of great importance for the future of children. The President stressed the need to apply the experience of South Korea in the preparation of projects for new kindergartens. At the same time, during his visit, he put forward the initiative to mark 2018 in Karakalpakstan as the "Year of Preschool Education"[6]. In the process of inspecting these facilities, "the construction of such facilities on the basis of old projects does not justify itself. We need to build children's dormitories and classrooms spacious and bright, and reduce the number of administrative rooms," the head of state said.

There was also a presentation of standard projects of pre-school educational institutions for 50, 100, 150 places. The new projects include the further expansion of the public and private sectors of preschool education, including the development of a healthy competitive environment, the introduction of new types of preschool education in public-private partnerships.

In 2018, the address list of a total of 179 preschool educational institutions in the city and districts of Nukus, which will be organized on the basis of public-private partnership, was developed and approved by the Council of Ministers of the Republic of Karakalpakstan. In the Republic of Karakalpakstan, on the basis of 19 public-private partnerships, 4 non-governmental and 66 family non-governmental preschool educational institutions have been launched.

Young people who graduated from the Pedagogical College were involved in retraining courses and instructed to recruit them to preschool educational institutions[6].

Conclusion

Preschool educational institutions under the Ministry of Public Education of the Republic of Karakalpakstan currently have 32,795 children in 310 educational institutions, which are taught by 3,110 teachers. Of these, more than 2,000 children are brought up in 19 special multidisciplinary and 4 sanatorium-type institutions for children from families with various health problems and infectious diseases.

The Ministry is taking a number of measures to develop the activities of kindergartens. In particular, the UNICEF project "Child-Oriented Education" in the country includes 15 preschool educational institutions from seven cities and districts: Nukus, Khojayli, Ellikkala, Beruni, Turtkul, Shumanay and Nukus districts. The main goal of the project is to involve more children in kindergartens in cooperation with local authorities, neighborhoods and parents. Relevant seminars are being held on this topic. Educators were not only taught how to teach on the basis of interactive and new pedagogical technologies, but also provided with methodical manuals, children's books, toys and other teaching aids. In the seminars organized for trainers and consultants in Nukus, Khojayli, Shumanay and Ellikkala districts, the decline in children's mastery was studied in detail. The council's findings were published in district newspapers. On the basis of the state administration 
"Year of Prosperity and Happiness" this year in Turtkul district held a seminar-training on the establishment of medical psychological and pedagogical commissions in preschool institutions of the Republic of Uzbekistan.

Every three years, teachers of preschool education institutions improve their skills in Tashkent and Nukus. At present, according to the plan, 61 kindergartens have been provided with the necessary equipment, teaching aids and toys[7].

In the 2017-2018 academic year, the involvement of preschool children in preschool education increased from $32.2 \%$ to $44.4 \%$ as of April 1, 2019, ie the enrollment rate increased by $12.2 \%$. This is definitely an important achievement in a year.

Today, the number of preschool educational institutions in the Republic of Karakalpakstan is 543, including 375 public, 6 private, 22 public-private partnerships, 2 enterprises, 136 non-governmental kindergartens. As of April 1 this year, the number of children aged 3-7 in the country was 150,974 , of which 1,208 children were enrolled in preschool education, 2,352 children in 136 family kindergartens, 259 children in preschool educational institutions, which is $44.4 \%$ of the country's total. formed In fact, in achieving such success, the following can be shown: There are 79 branches of pre-school educational institutions under the Ministry of Preschool Education of the Republic of Karakalpakstan, which have been fully inventoried and 60 branches of pre-school educational institutions, which are considered satisfactory, have been given legal status and established as separate pre-school educational institutions.

\section{References}

1.Collection of Legislation of the Republic of Uzbekistan, 2007, No. 43, Article 431; 2011, No. 25, Article 260; 2017, No. 30, Article 732

2.Resolution of the Board of the Ministry of Public Education of the Republic of Karakalpakstan on the implementation of educational reforms and future tasks in accordance with the requirements of the Law "On Education" and the "National Training Program" of the Ministry of Public Education of the Republic of Karakalpakstan.

3. UstazJoly newspaper. 17.11.2012 SardarTajievUzA correspondent.

4. ErkinKarakalpakstan newspaper 11.09.2017

5. President ShavkatMirziyoyev began his visit to the Republic of Karakalpakstan from preschool No. 8 in Chimbay district // http://uza.uz/uz/posts/president-shavkat-mirziyeevora-alpo-iston-respublikasig-15-12-2017

6. Erkin Karakalpakstan newspaper 22.01.2017 and Karakalpakstan news agency

7.Erkin Karakalpakstan newspaper and Karakalpakstan news agency
8. Мамбетова, И. Ж. (2016). The functional role of the national and cultural factors in teaching (learning) foreign language. Педагогикавысшейшколь, (2), 38-41. 9. Kerimbergenovich, A. A., Kamilovich, S. S., Tursinbaevich, A. R., Jannazarovich, A. K., Kazievich, S. J., \&Maksetovich, O. H. (2020). Ecotourism development in the republic of karakalpakstan: Historical places and protected areas. Journal of Critical Reviews, 7(12), 12581262. doi:10.31838/jcr.07.12.220

10. Bayrieva, A. (2020). Ensuring balance among branches of public power during the development of civil society in uzbekistan. EuropeanJournalofMolecularandClinic alMedicine, 7(2), 2233-2239.

11. Kojageldiev, A. (2020). Constitutionalism as the basic principle of democratization and modernization of the socio-political system of the republic of uzbekistan and the republic of karakalpakstan. International Journal of Advanced Science and Technology, 29(5), 1619-1625.

12. Utepbergenov, F., Tolibaev, M., Turebekov, M., Khakimniyazov, J., Kdyrniyazov, O. S., Saypov, S., \&Alimbetov, A. DEVELOPMENT OF A CRAFT COMPLEX IN THE MEDIEVAL QUARTERS OF THE CITY OF MIZDAKHKAN. EuropeanJournalofMolecular\& ClinicalMedicine, 7(11), 4021-4032.

13. Maksetbaevich, O. K. (2020). Ethnodemographicprocesess at the headquarters of amudarya on the EVE of the 1916 uprising. JournalofCriticalReviews, 7(11), 391395. doi:10.31838/jcr.07.11.69

14. Abdullaeva, B., Ibragimov, J., \&Abullaev, T. (2020). Methodology of improvement of educational activities at the university. Journal of Advanced Research in Dynamical and Control Systems, 12(2), 2725-2728. doi:10.5373/JARDCS/V12I2/S20201329

15. Abilovich, Y. K. (2020). Scientific and theoretical foundations of teaching karakalpak literature at academic lyceums. JournalofCriticalReviews,7(7), 349-354. doi:10.31838/jcr.07.07.57

16. Pirnazarov, N. (2020). Philosophical analysis of the issue of spirituality. InternationalJournalofAdvancedScienc eandTechnology,29(5), 1630-1632.

17. Berdimuratova, A. K., \& Mukhammadiyarova, A. J. (2020). Philosophical and methodological aspects of the interaction of natural environment and

man. InternationalJournalofPharmaceuticalResear ch, 12(3),

1722-1727. doi:10.31838/ijpr/2020.12.03.235

18. Elizaveta, K., Govkherjan, Y., \& Abdurashidovha, M. F. (2020). The problem of good and evil in the world according to the philosophical teachings of 
avecinna. InternationalJournalofAdvancedSciencea ndTechnology,29(5), 2415-2428.

19. Palimbetova, M. (2020). Problems of genre, artistic language and artistic methods in karakalpak dramaturgy during the independence period. Journal of Advanced Research in Dynamical and Control Systems, 12(6), 1037-1042. doi:10.5373/JARDCS/V12I6/S20201128

20. Turganbay, O. (2020). Prerequisites for the development of karakalpak literary studies at the beginning of the 21 st century. Journal of Advanced Research in Dynamical and Control Systems, 12(6), 1031-1036.

doi:10.5373/JARDCS/V12I6/S20201127

21. Janabergenovich, A. A. (2019). Formation of technological competence in students: Essence and content. International Journal of Recent Technology and Engineering,8(2 Special Issue 10), 367-369. doi:10.35940/ijrte.B1060.0982S1019
22. .Pirnazarov, N. R. ul1. (2020). INFLUENCE OF VIRTUAL REALITY ON THE SPIRITUALITY OF INFORMATION SOCIETY. EurasianUnionScientists.

https://doi.org/10.31618/esu.24139335.2020.2.71.587

$23 . \quad$ Berdimuratova

A, «TileubergenJumamuratovshıǵarmashılıǵffilosofiya lıqanalizdińob'ektiretinde», Adamálemi 3 (85) 2020, 19-28

24.

KurmanovAibekPuharbaevich, IbragimovBayniyazAytbaevich.

(2020). Psychological-pedagogical features of studying enterprise (entrepreneurship education in the system of public education). PalArch's Journal of Archaeology of Egypt / Egyptology, 17(7), 1294712950. Retrieved from https://archives.palarch.nl/index.php/jae/article/vie $\underline{w} / 4975$ 